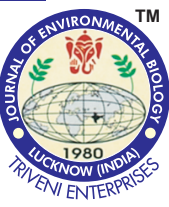

\title{
Effect of melatonin and pinealectomy on gonadal activity during prespawning period of catfish (Heteropneustes fossilis)
}

\begin{tabular}{lll}
\hline Paper received: 16.05 .2018 & Revised received: $15.09 .2018 \quad$ Re-revised received: $10.12 .2018 \quad$ Accepted: 04.03 .2019 \\
\hline
\end{tabular}

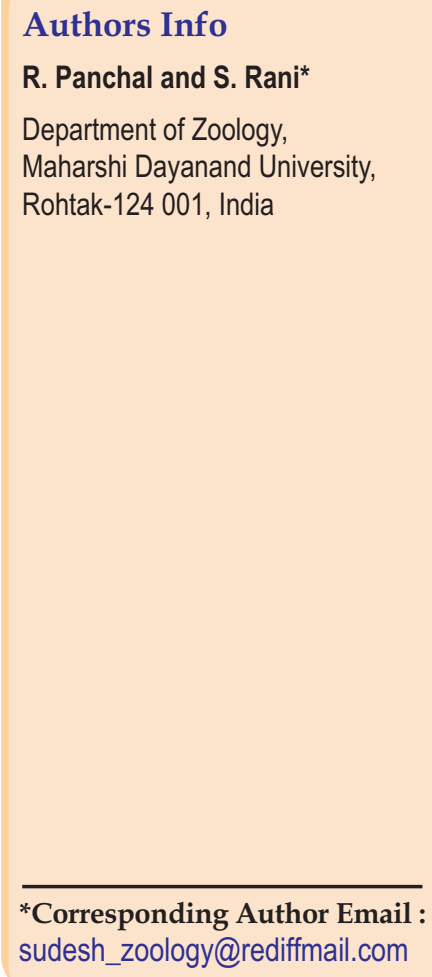

\section{Edited by \\ Dr. Zeba Zaffer Abidi}

Reviewed by

Dr. Kamal Sharma

Dr. R.B. Raizada

\section{Abstract}

Aim : The effects of intraperitoneal administration of melatonin dose $(25,50,100,200$ and $400 \mathrm{mg}$ per fish) on gonadal activities were evaluated during the prespawning period of catfish, Heteropneustes fossilis for 60 days.

Methodology : In this experiment, fourteen aquariums were used because the experiment was performed in replicate and fifteen fishes were suspended in each glass aquarium. One group of male and female catfishes were considered as control group and the catfishes in the second group were pinealectomized whereas the remaining five treatments were administered with low (25, $50 \mathrm{mg}$ per fish) and high (100, 200, $400 \mathrm{mg}$ per fish) doses of melatonin.

Results : During prespawning period of reproductive cycle, the gonado-somatic index of ovary of pinealectomized and melatonin treated fish decreased as compared to the control group. The number of yolky oocytes significantly decreased in the melatonin treated group as compared to the control group. After 60 days of pinealectomy, it showed inhibitory effects on the ovarian activity. The GSI of testes of pinealectomized fish decreased as compared to the control group. The number of spermatozoa cells increased with the increase in the melatonin dose as compared to control group. The GSI of testes was found maximum in the melatonin treated group as compared to the control group.

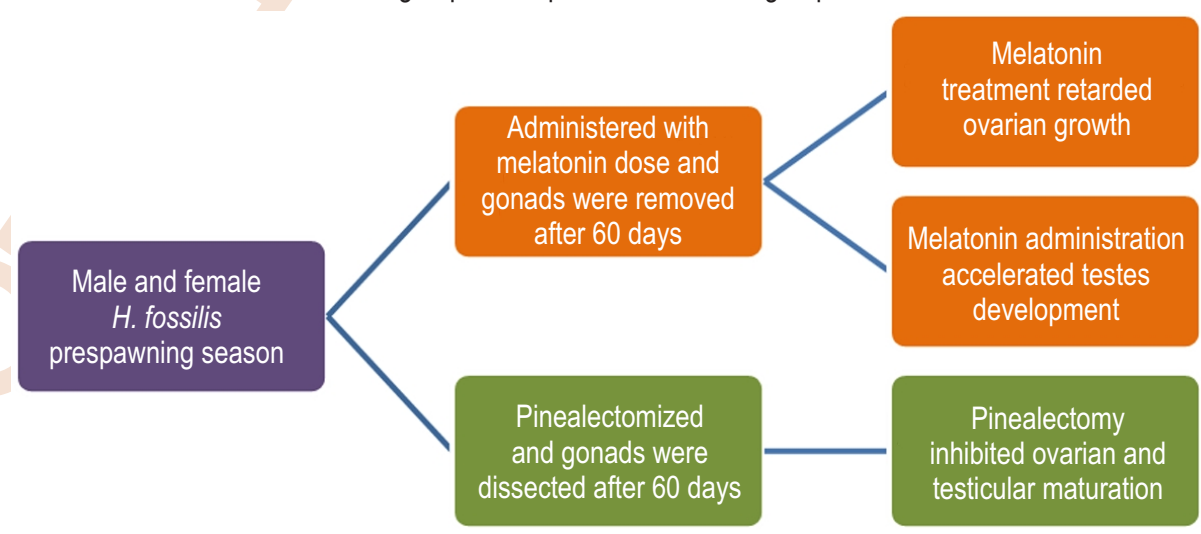

Interpretation : This study supports the concept that melatonin hormone administration helps in maturation of testes and increases the number of spermatozoa. This was just contrary to the results obtained in female catfish where melatonin treatment showed inhibitory effects on the ovarian activity during prespawning period.

Key words: Catfish, Gonads, Melatonin, Pinealectomy, Prespawning period

How to cite : Panchal, R. and S. Rani: Effect of melatonin and pinealectomy on gonadal activity during prespawning period of catfish (Heteropneustes fossilis). J. Environ. Biol., 40, 698-704 (2019). 


\section{Introduction}

World's greatest challenge in near future is to feed a population of 9.6 billion and in this fisheries/aquaculture plays a significant role as they are considered as protein manufacturing industry (FAO, 2014). Heteropneustes fossilis is commonly cultured species all over India. It has the ability to survive in oxygen depleted waters compared with major carp species (Khan, 2014). H. fossilis feed on artificial diets at increased temperature and are able to withstand shifts in salinity (Thakur 1991). Its flesh has high therapeutic and nutritional value and has high fecundity (Khan, 2014) and low production cost. H. fossilis is locally known as "Shingi" and can survive for maximum time when placed in captivity even in less amount of water (Narejo et al., 2005). Further, in these fishes a number of physiological activities are carried out by pineal organ. Pineal gland is formed as an evagination from the embryonic features which consist of pineal stalk and end vesicle. Pineal gland releases an important hormone, melatonin that plays an important role via functioning of hypothalamo-hypophysial gonadal axis to establish seasonal reproduction in fishes (Reiter, 1986; Mazurais et al., 2000). In fishes, secretion of melatonin is regulated by photoperiod. In pinealectomized fishes, the amount of melatonin is reduced.

During prespawning period, the hepatic synthesis of vitellogenin and its incorporation into the developing oocytes occurs, which results in the increase in ovarian weight with the development of yolky oocytes. Reproductive organs have melatonin receptors, thus melatonin affects the function of testis and ovary (Falcon et al., 2007). Pineal gland and/or melatonin regulates the seasonal development of gonads in fish (Bromage et al., 2001; Maitra et al., 2001, 2006; Bayarri et al., 2004). It also has inhibitory effect on ovarian vitellogenesis, plasma GtH I levels and GSI in Clarias batrachus (Ghosh and Nath, 2005), and affect the oocyte development in carps (Chattoraj et al., 2005). The main source of melatonin hormone is pineal gland but severa studies have reported that gastrointestinal tract and retina also release small amount of melatonin in fish (Mayer, 2000; FernandezDuran et al., 2007) after pinealectomy. Fish seasonality has been demonstrated in fish species, but only some direct evidences exist that show how melatonin hormone influence brain-pituitary-gonadal axis to control reproduction, feed intake and growth. The complex effect of melatonin hormone on fish reproduction still awaits a more precise and complete knowledge. The objective of this study was to investigate the effect of pinealectomy and melatonin administration on the gonadal activity in $\mathrm{H}$. fossilis, during prespawning period, when vitellogenic activity is at peak.

\section{Materials and Methods}

Experimental area : This experiment was carried out in the Fisheries/ Animal Biology and Behavior Laboratory, Department of Zoology, Maharshi Dayanand University, Rohtak, India.

Experiment set up : Male and female $H$. fossilis (mean body weight 20-50 gm) were procured from Sultan Aqua Integrated
Education and Research Foundation V.P.O. Nilokheri Karnal, Haryana. Before start of the experiment the fishes were acclimatized for 15 days under laboratory conditions, photoperiod (LD 12:12) and temperature $25 \pm 1^{\circ} \mathrm{C}$. The experiment was carried out for 60 days. This experiment was performed in replicate, thus 14 aquariums were used and 15 fishes were suspended in each glass aquarium $(60 \times 30 \times 30 \mathrm{~cm})$. Melatonin injections were given to 150 male and female fishes out of 210 fishes. Initial weight of the fishes were recorded before the experiment and the fishes were fed with formulated feed in the morning (at 8 a.m.) and in the evening (at 5 p.m.) @ 5\% of their body weight. The water of each aquarium was restored with the stored tap water daily.

Pinealectomy : Pinealectomy (Px) of fishes was done by following the procedure of Francis et al. (2004). The fishes were anesthetized by tricaine methanesulfonate and posterior to the pineal window, a horizontal incision was made, which is clearly visible through the skin. The pineal gland is clearly visible when a flab of tissue was moved anteriorly. The pineal stalk was then removed from diencephalon and the pineal gland was extracted with the help of forceps and the area was cleaned with $70 \%$ ethanol. All procedure was done under binocular microscope.

Melatonin : Melatonin solution was prepared following the method of Ghosh and Nath (2005). Melatonin $(25,50,100,200$ and $400 \mathrm{mg}$ ) was dissolved in $(2,4,8,16$ and $32 \mathrm{ml})$ of $100 \%$ ethanol and diluted with teleost saline $\left(20 \mathrm{mg} \mathrm{Na}_{2} \mathrm{CO}_{3}\right.$ per $100 \mathrm{ml}$ of $0.6 \% \mathrm{NaCl})$ to acquire the final desired concentration $(25,50$, 100,200 and $400 \mathrm{mg}$ per $0.1 \mathrm{ml}$ ). Every week fresh solution of melatonin was prepared and stored in dark bottles in at $4^{\circ} \mathrm{C}$. Melatonin injections were given to fishes after 2 p.m.

Experimental procedure : Intra-peritoneal injections of $0.1 \mathrm{ml}$ melatonin were given to fishes thrice a week close to the ventral midline posterior to the pelvic fins following the procedure of $\mathrm{De}$ Vlaming (1980). Melatonin dose was given to the fishes according to Singh and Lal (1994). After 60 days of experiment, final weight of the fishes were calculated.

Live weight gain was calculated by the following formula :

$$
\begin{aligned}
& \text { Live Weight Gain }(\mathrm{g})=\mathrm{W}_{2}-\mathrm{W}_{1} \\
& \text { where, } \mathrm{W}_{2}=\text { final weight }(\mathrm{g}) ; \mathrm{W}_{1}=\text { initial weight }(\mathrm{g})
\end{aligned}
$$

Gonadosomatic Index (GSI) : After 60 days, male and female $H$. fossils were randomly selected from each treatment to calculate the GSI of each individual by the following formula :

$$
\mathrm{GSI}=\frac{\text { Gonad weight }(\mathrm{g})}{\text { Body weight }(\mathrm{g})} \times 100
$$

Histological examination : Anesthetized catfish (male and female) were dissected and the gonads were fixed in $10 \%$ formalin for $24 \mathrm{hr}$. The gonads were then dehydrated in alcohol and then transferred from $100 \%$ alcohol to a mixture of $100 \%$ 


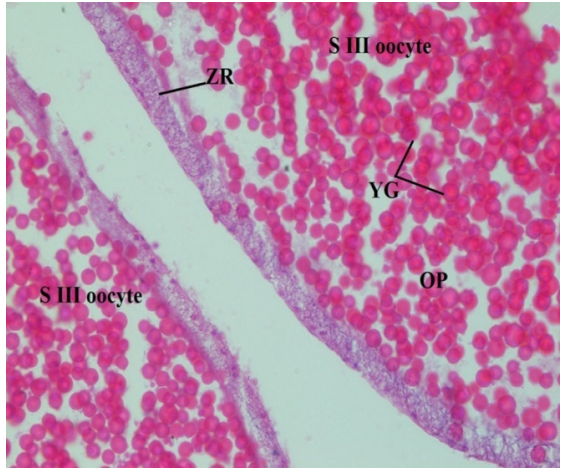

(A) (Control)

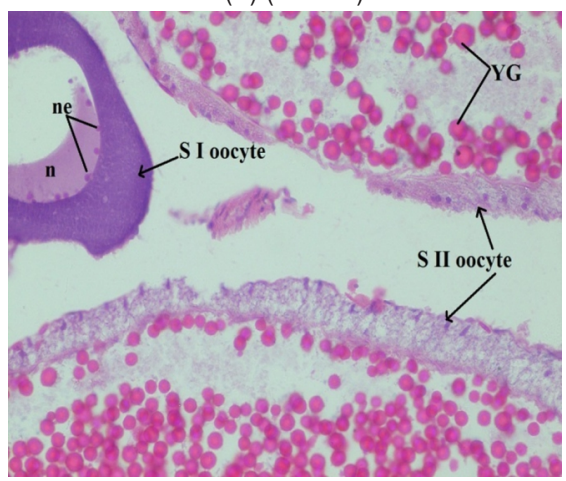

(C) $(25 \mathrm{mg}$ melatonin)

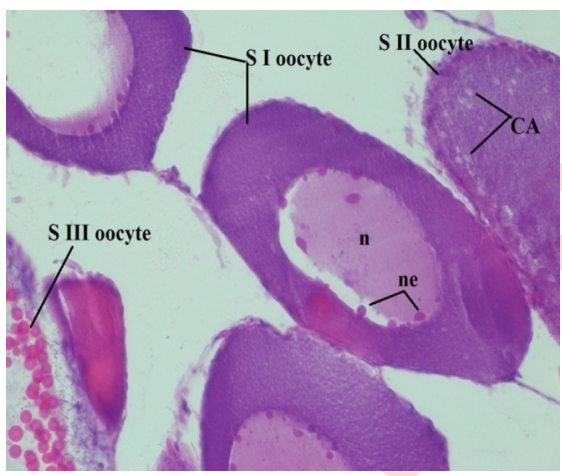

(E) (100 mg melatonin)

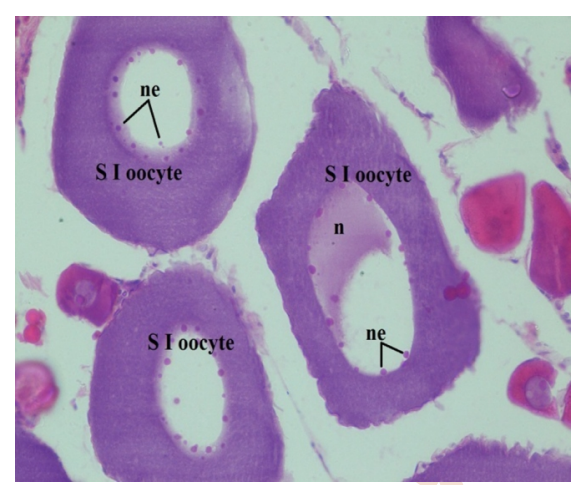

(B) (Pinealectomized)

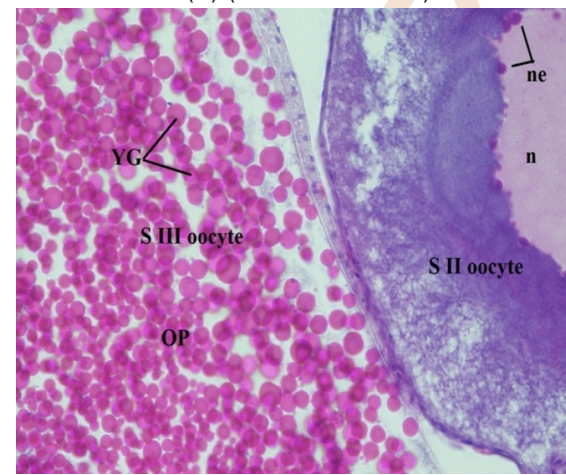

(D) (50 mg melatonin)

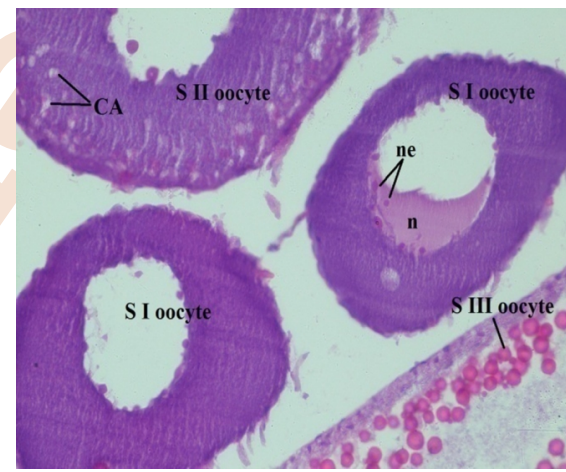

(F) (200 mg melatonin)

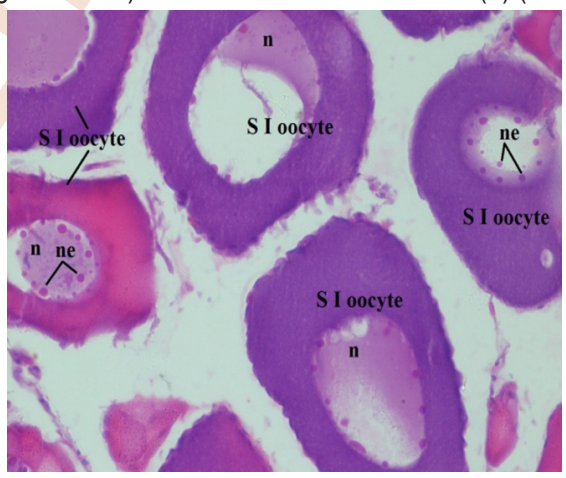

(G) (400 mg melatonin)

Fig.1 : Light micrograph of pinealectomized and melatonin treated, $H$. fossilis ovaries during pre-spawning period showing different stages of development (H\&E stain $\times 400)$. T.S. of ovary $(A)$ more SIII oocyte with increasing number. of acidophilic yolk granules incorporated in ooplasm; (B) large number of SI oocyte, large centrally placed nucleus bearing ring of nucleoli enveloped by follicular epithelium; (C) more SI and less SII (cortical alveoli at the periphery of oocyte); (D) S II and S III oocyte; (E) and (F) more SI, less S II, and SIII oocyte and (G) only S I oocyte. T.S.: transverse section, ZR : Zona radiata, YG : yolk globules, OP : ooplasm, $\mathrm{N}$ : nucleus, ne : nucleoli, $\mathrm{CA}$ : Cortical alveoli. 


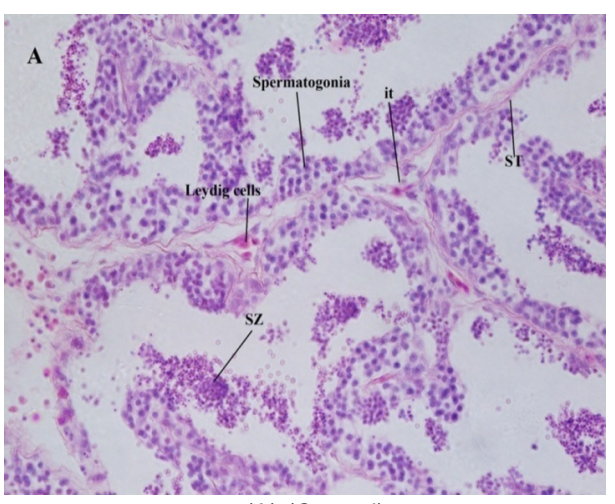

(A) (Control)

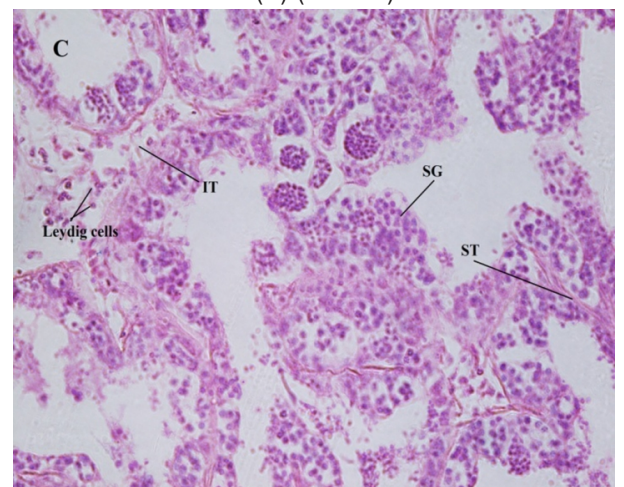

(C) (25 mg melatonin)

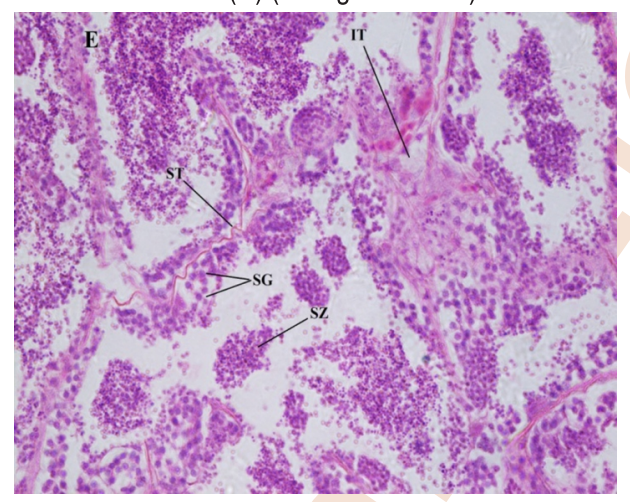

(E) (100 mg melatonin)

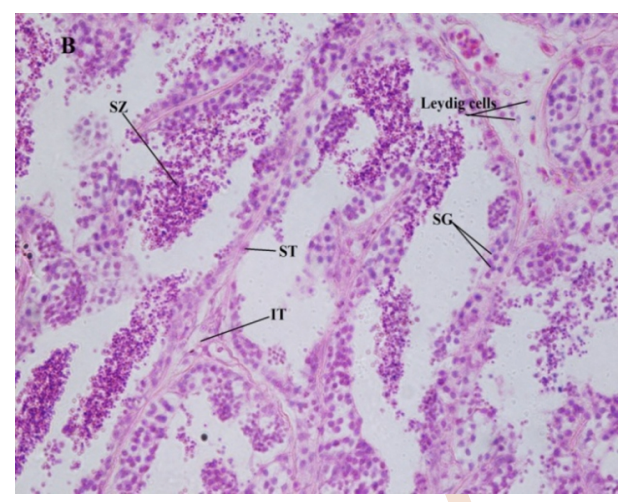

(B) (Pinealectomized)

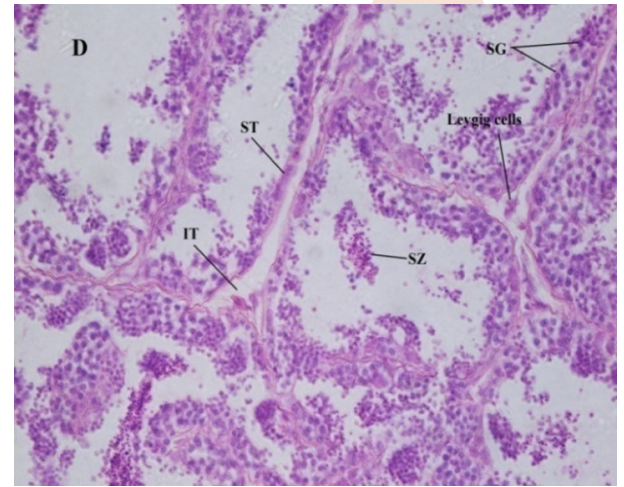

(D) (50 mg melatonin)

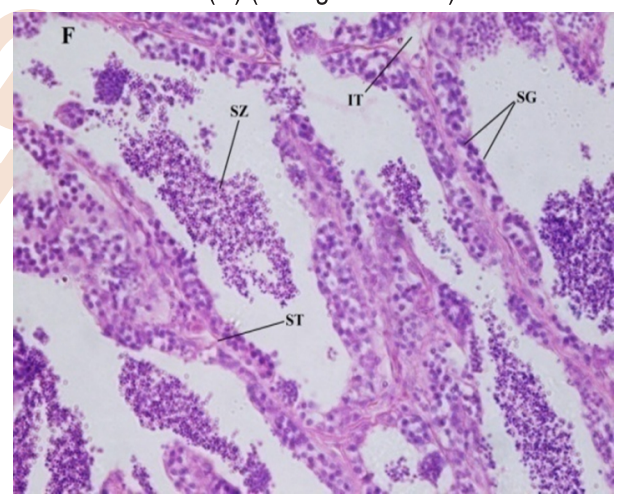

(F) (200 mg melatonin)

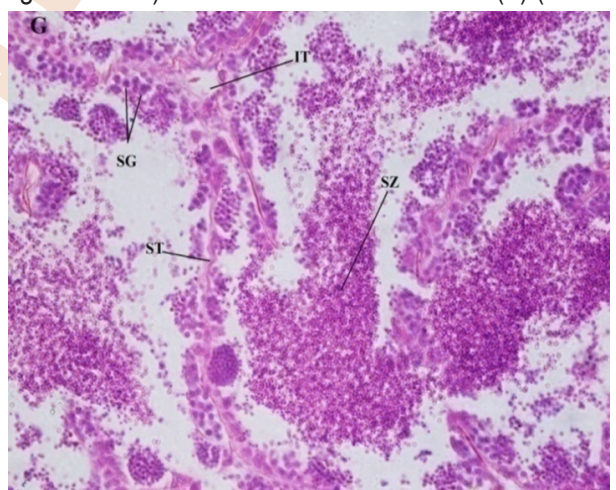

(G) (400 mg melatonin)

Fig. 2 : Light micrograph of $H$. fossilis testis during pre- spawning period (H\&E stain $\times 400)$. (A-B) T.S. of testis shows increased interstitial tissue and intact spermatogonia; (C-G) T.S. of testis shows increased number of Leydig cells and spermatogenic cells and SG- spermatogonia, ST- seminiferous lobules, SZ- spermatozoa, IT-interstitial tissue. 
alcohol and xylene (1:1) for 30 min. After dealcoholisation, the gonads were treated with a mixture of xylene and paraffin wax (1:1) for $30 \mathrm{~min}$ in oven at $58^{\circ} \mathrm{C}$, just above the melting point of paraffin wax, and then the tissue was transferred to pure paraffin wax for $30 \mathrm{~min}$. Metallic 'L' moulds were used for the block formation of the tissue and the tissues were sectioned with the help of microtome, which was adjusted to 5-7 micron. The sections of tissue or ribbon were then placed on the glass slide on which a small layer of egg albumen was applied on the surface of the slide and after that the slide was slightly heated.

Slide formation and mounting : The glass slide was then transferred to the coupling jar filled with xylene for 10 minutes and then the slides were submerged in 100\% alcohol for $10 \mathrm{~min}$. The slides were kept in coupling jar for 5 minute each in descending order of ethanol $100 \%, 70 \%, 50 \%$ and $30 \%$. The slides were then placed in haematoxylin stain for $5 \mathrm{~min}$ and immediately transferred to acid water for $2 \mathrm{~min}$. The slides were placed in ascending grades of alcohol $30 \%, 50 \%, 70 \%$ and then stained with eosin for $5 \mathrm{~min}$. After staining with eosin the slides were transferred in $90 \%$ and $100 \%$ ethanol for $5 \mathrm{~min}$. After dehydration, the slides were placed in xylene for $10 \mathrm{~min}$. Canada balsam or DPX was applied on the glass slide and immediately the cover slip was placed on the slide (Singh et al., 2012).

Statistical analyses : One-way ANOVA was applied on the data of body weight and GSI of male and female catfish to analyze the significance between the treated group and control group followed by Tukey's honest significance test.

\section{Results and Discussion}

Throughout the experiment, the fishes were found healthy and no mortality was recorded in the control, pinealectomized and melatonin treated groups. After 60 days of experiment, the final weight of male and female $H$. fossilis of control group was maximum as compared to pinealectomized and melatonin treated groups (Table 1). Histological changes in the ovary and testes of treated and control group were observed in $H$. fossilis during the prespawning period (May-June) of reproductive growth. During prespawning period, the ovary of $H$. fossilis consist large number of yolky oocytes. In females, the GSI in control group increased during the prespawning period as compared to the melatonin treated and pinealectomized group. The results showed that in male $H$. fossilis, the GSI of control group and pinealectomized group decreased as compared to melatonin treated group. The values of significance between the groups for female and male GSI was $p \leq 0.05$ and the C.V. value for female was 5.07 and male 20.19 , respectively.

The histopathological study revealed that the number of stage III oocytes increased in the control group. The stage I oocyte or previtellogenic oocytes showed a significant increase with the increase in melatonin dose (Fig.1. C,E,F and G) when compared with the control group (Fig.1. A). The number of stage II and stage III oocytes decreased when melatonin dose was increased. After 60 days of pinealectomy, the number of Stage I, Stage II and Stage III oocytes decreased significantly. In male $H$. fossilis, the melatonin treatment increased the number of spermatozoas (Fig.2. C-G) as compared to pinealectomized (Fig.2. B) and control (Fig.2. A) group. The histopathological study showed that the ovary of melatonin treated female catfish suppressed the developing stage of ovary (Fig.1) whereas melatonin treatment in male $H$. fossilis increased the GSI (Table 1) and number of spermatozoa (Fig. 2). These results favored the study carried on Clarias macrocephalus where melatonin act as an important reproduction regulating hormone in male catfish, and its dose increased the first puberty stage in male catfish (Aripin et al., 2014).

In Oncorhynchus mykiss, the melatonin administration decreased the body weight (Taylor et al., 2005). The melatonin treatment in gold fish reduced the body weight which suggested that it may be due to less food intake caused due to melatonin dose (Pinillos et al., 2001). In the present study, it was observed

Table 1: Effect of pinealectomy (Px) and melatonin (MET) dose on body weight (g) and GSI of cattish, Heteropneustes fossilis under laboratory conditions

\begin{tabular}{|c|c|c|c|c|c|c|c|}
\hline Parameters & Control & Px & $25 \mathrm{mg}$ & $50 \mathrm{mg}$ & $100 \mathrm{mg}$ & $200 \mathrm{mg}$ & $400 \mathrm{mg}$ \\
\hline Initial weight & $\begin{array}{l}18.07 \\
\pm 0.05\end{array}$ & $\begin{array}{l}19.91 \\
\pm 0.02\end{array}$ & $\begin{array}{l}20.40 \\
\pm 0.01\end{array}$ & $\begin{array}{l}20.49 \\
\pm 0.02\end{array}$ & $\begin{array}{l}18.46 \\
\pm 0.03\end{array}$ & $\begin{array}{l}24.62 \\
\pm 0.01\end{array}$ & $\begin{array}{l}20.55 \\
\pm 0.99\end{array}$ \\
\hline Final weight & $\begin{array}{l}21.12 \\
\pm 0.02\end{array}$ & $\begin{array}{l}19.16 \\
\pm 0.01\end{array}$ & $\begin{array}{l}18.50 \\
\pm 0.03\end{array}$ & $\begin{array}{l}17.96 \\
\pm 0.03\end{array}$ & $\begin{array}{l}15.67 \\
\pm 0.02\end{array}$ & $\begin{array}{l}21.15 \\
\pm 0.05\end{array}$ & $\begin{array}{l}16.47 \\
\pm 0.02\end{array}$ \\
\hline $\begin{array}{l}\text { Live weight gain } \\
\text { (male and female) }\end{array}$ & $\begin{array}{l}3.05 \\
\pm 0.03\end{array}$ & $\begin{array}{l}-0.75 \\
\pm 0.01\end{array}$ & $\begin{array}{l}-1.91 \\
\pm 0.04\end{array}$ & $\begin{array}{l}-2.54 \\
\pm 0.01\end{array}$ & $\begin{array}{l}-2.79 \\
\pm 0.05\end{array}$ & $\begin{array}{l}-3.48 \\
\pm 0.06\end{array}$ & $\begin{array}{l}-4.09 \\
\pm 0.96\end{array}$ \\
\hline GSI (Female) & $\begin{array}{l}16.05 \\
\pm 0.07\end{array}$ & $\begin{array}{l}15.06 \\
\pm 0.19\end{array}$ & $\begin{array}{l}12.48 \\
\pm 0.70\end{array}$ & $\begin{array}{l}11.76 \\
\pm 0.68\end{array}$ & $\begin{array}{l}10.83 \\
\pm 0.19\end{array}$ & $\begin{array}{l}8.79 \\
\pm 0.21\end{array}$ & $\begin{array}{l}8.58 \\
\pm 0.35\end{array}$ \\
\hline GSI (Male) & $\begin{array}{l}0.94 \\
\pm 0.03\end{array}$ & $\begin{array}{l}0.73 \\
\pm 0.04\end{array}$ & $\begin{array}{l}0.84 \\
\pm 0.04\end{array}$ & $\begin{array}{l}0.95 \\
\pm 0.01\end{array}$ & $\begin{array}{l}1.43 \\
\pm 0.46\end{array}$ & $\begin{array}{l}1.60 \\
\pm 0.08\end{array}$ & $\begin{array}{l}1.71 \\
\pm 0.04\end{array}$ \\
\hline
\end{tabular}

Values are mean of two replicates \pm S.E. 
that the melatonin injection causes antigonadal effects by inhibiting the ovarian activity during prespawning period in catfish, $H$. fossilis. Exogenous administration of melatonin $100 \mathrm{mg} / 100 \mathrm{~g}$ body weight/day showed accelerated oocyte growth in the preparatory period of reproductive cycle but the prespawning and spawning period was retarded in Catla catla (Mondal et al., 2016). Melatonin administration $(25,50$ and $100 \mu \mathrm{g})$ for 60 days inhibited the ovarian development in carp, Catla catla during prespawning season of reproduction (Maitra and Chattoraj, 2007). Melatonin dose $(25,50$ or $100 \mu \mathrm{g}$ per $100 \mathrm{~g} \mathrm{b.wt}$.) decreased the number of stage II oocyte in Catla catla when compared to the control group during prespawning season, which indicated that melatonin dose suppressed ovarian maturation (Maitra et al., 2005). During the prespawning phase, melatonin treatment decreased the GSI in female carp, Catla catla (Mondal et al., 2016) where melatonin treatment in $H$. fossilis for 20 days during prespawning period inhibited vitellogenesis, induced follicular atresia and decreased the number of pituitary gonadotrophs. In a histological study carried out by Aripin et al. (2014) in male C. macrocephalus where the spermatogonia cells are maximum in control group and the spermatids and spermatozoa are in abundance in the melatonin treated group, which shows that melatonin administration increase the maturity in this fish. Melatonin treatment to fish inhibits the somatic and gonadal growth in O. niloticus (Singh et al., 2012).

It also plays a significant role in the annual testicular regulation (Bhattacharya et al., 2007). In C. macrocephalus melatonin feeding increased the maturation of sperm and testes (Aripin et al., 2015), these results also resemble with the present study. This investigation showed that the Pinealectomy and melatonin dose causes inhibitory effects on the ovarian activity whereas melatonin treatment stimulates testes development during the prespawning period of catfish.

The information gathered in the present study collectively enhances the idea that exogenous melatonin administration and pinealectomy cause inhibitory effects on the ovarian development whereas exogenous melatonin treatment enhances the maturation of testes but pinealectomy retarded the testes development in $H$. fossilis during prespawning period of reproductive growth.

\section{Acknowledgment}

This investigation was supported by the University Research Fellowship grant Maharshi Dayanand University, Rohtak, Haryana, India.

\section{References}

Aripin, S.A., O. Jintasataporn and R. Yoonpundh: Effects of melatonin in Clarias macrocephalus male broodstock first puberty. Proceeding of International Conference of Aquaculture Indonesia, pp. 209-215 (2014).

Aripin, S.A., O. Jintasataporn and R. Yoonpundh: Effects of melatonin on Clarias macrocephalus female broodstock performance. Int. J.
Scie.: BasicApp. Res., 21, 129-137 (2015)

Bayarri, M.J., L. Rodriguez, S. Zanuy, J.A. Madrid, F.J. SanchezVazquez, H. Kagawa, K. Okuzawa and M. Carrillo: Effect of photoperiod manipulation on the daily rhythms of melatonin and reproductive hormones in caged European sea bass (Dicentrarchus labrax). Gen. Comp. Endocrinol., 136, 72-81 (2004).

Bhattacharya, S., A. Chattoraj and S.K. Maitra: Melatonin in the regulation of annual testicular events in carp Catla catla: Evidence fron the studies on the effects of exogenous melatonin, continuous light and continuous darkness. Chronobiol. Int., 24, 629-650 (2007).

Bromage, N., M. Porter and C. Randall: The environmental regulation of maturation in farmed finfish with special reference to the role of photoperiod and melatonin. Aquaculture, 197, 63-98 (2001).

Chattoraj, A., S. Bhattacharyya, D. Basu, S. Bhattacharya and K. Maitra: Melatonin accelerates maturation inducing hormone $(\mathrm{MIH})$ induced oocyte maturation in carps. Gen. Comp. Endocrinol., 140, 145-155 (2005).

De Vlaming, V.L.: Effect of pinealectomy and melatonin treatment on growth in goldfish, Carassius auratus. Gen. Comp. Endocrinol., 40, 245-250 (1980).

Falcon, J., L. Besseau, S. Sauzet and G. Boeuf: Melatonin effects on the hypothalamo-pituitary axis in fish. Trends Endicrinol. Metab., 18, 81-88 (2007).

FAO: The state of world fisheries and aquaculture. FAO Fisheries and Aquaculture Department, Rome, Italy. p. 22 (2014).

Fernandez-Duran, B., C. Ruibal, S. Polakof, R.M. Ceinos, J.L. Soengas and J.M. Miguez: Evidence for arylaklylamine $\mathrm{N}$-acetyltransferase (AANAT2) expression in rainbow trout peripheral tissues with emphasis in the gastrointestinal tract. Gen. Comp. Endocrinol., 152, 289-294 (2007).

Francis, T., N. Ramanathan and P. Padmavathy: Role of the pineal organ and melatonin in fish. World Aquacul., 35, 21-69 (2004).

Ghosh, J. and P. Nath: Seasonal effects of melatonin on ovary and plasma gonadotropin and vitellogenin levels in intact and pinealectomized catfish Clarias batrachus (Linn). Ind. J. Exp. Biol., 43, 224-232 (2005)

Khan, M. A.: Dietary L-tryptophan requirement of fingerling stinging catfish, Heteropneustes fossilis (Bloch). Aquacul. Res., 7, 12241235 (2014).

Maitra, S.K. and A. Chattoraj: Role of photoperiod and melatonin in the regulation of ovarian functions in Indian carp Catla catla: Basic information for future application. Fish Physiol. Biochem., 4, 367 (2007).

Maitra, S.K., A. Chattoraj and S. Bhattacharyya: Implication of melatonin in oocyte maturation in Indian major carp Catla catla. Fish Physiol. Biochem., 31, 201 (2005).

Maitra, S.K., M. Seth and A. Chattoraj: Photoperiod, pineal photoreceptors and melatonin the signal of photoperiod in the regulation of reproduction in fish. J. Endocrinol. Reprod., 10, 73-87 (2006).

Maitra, S.K., R. Dey and S. Bhattacharya: Seasonal reproduction in fish: A functional interplay between the pineal organ and photoperiods. J. Endocrinol. Reprod., 5, 1-12 (2001).

Mayer, I.: Effect of long-term pinealectomy on growth and precocious maturation in Atlantic salmo, Salmo salar parr. Aquat. Living Resour., 13, 139-144 (2000).

Mazurais, D., M. Portar, C. Lethimonier, G. Le Drean, P. Le Goff, C. Randall, F. Pakdel, N. Bromage and O. Kah: Effects of melatonin on liver estrogen receptor and vitellogenin in rainbow trout: $A n$ in vitro and in vivo study. Gen. Comp. Endocrinol., 118, 344 (2000).

Mondal, P., K.N. Hasan, P.K. Pal and S.K. Maitra: Influences of exogenous melatonin on the oocyte growth and oxidative status of 
ovary during different reproductive phases of an annual cycle in carp Catla catla. Theriogenology, 87, 1-16 (2016).

Narejo, N.T., M.A. Salam, M.A. Sabur and S.M. Rahmatullah: Effects of stocking density on growth and survival of indigenous catfish Heteropneustes fossilis (Bloch) reared in cemented cistern fed on formulated feed. Pakistan J. Zool., 37, 49-52 (2005).

Pinillos, M.L., N. De Pedro, A.L. Alonso-Gómez, M. Alonso-Bedate and M. Delgado: Food intake inhibition by melatonin in goldfish (Carassius auratus). Physiol. Behavior., 72, 629-634 (2001).

Rani, S. and V.P. Sabhlok: Effect of melatonin administration on growth and metabolism of catfish Clarias batrachus under different photoperiods. J. Int. Aca. Res. Multidisciplin., 2, 627-635 (2014).

Reiter, R.J.: Action spectra, dose response relationships, and temporal aspects of light's effects on the pineal gland. Ann NY Acad Sci.,
453, 215(1986).

Singh, R., A.K. Singh and M. Tripathi: Melatonin induced changes in specific growth rate, gonadal maturity, lipid and protein production in Nile tilapia Oreochromis niloticus (Linnaeus 1758). Asian-Aust. J.Anim. Sci., 25, 37-43 (2012).

Singh, T.P. and P. Lal: Endocrine physiology of reproduction in Indian catfish. In: Advances in Fish Biology (Ed.: H.R. Singh). Hindustan Publishing Corporation, Delhi, India, pp. 147-154 (1994).

Taylor, J.F., H. Migaud, M.J.R. Porter and N.R. Bromage: Photoperiod influences growth rate and plasma insulin-like growth factor-I levels in juvenile rainbow trout, Oncorhynchus mykiss. Gen. Compa. Endocrinol., 142, 169-185(2005).

Thakur, N.K.: Possibilities and problems of catfish culture in India. J. Inland Fish Soc. India, 23, 80-90 (1991). 